\title{
Biosynthesis of Ethylene
}

\section{FORMATION OF ETHYLENE FROM METHIONAL BY A CELL-FREE ENZYME SYSTEM FROM CAULIFLOWER FLORETS}

\author{
By L. W. MAPSON AND D. A. WARDALE \\ Low Temperature Research Station, Downing Street, Cambridge
}

(Received 1 August 1966)

\begin{abstract}
1. The formation of ethylene from cauliflower florets is stimulated by the addition of either methionine or its hydroxy analogue. 2. Formation of ethylene from these compounds may also be demonstrated in cell-free extracts, but the most rapid formation is achieved by the addition of methional. 3. Fractionation of such extracts has shown that both particulate and non-particulate fractions are necessary for the formation of ethylene from methionine or its hydroxy analogues, but only the non-particulate fraction is necessary for its formation from methional. 4. A study of this system has shown that the conversion of methional into ethylene requires the presence of two enzyme systems, the first generating peroxide and the second catalysing the conversion of methional into ethylene in the presence of peroxide. 5. The presence of a heat-stable factor in cauliflower extracts that is necessary for the full activity of the enzyme converting methional into ethylene has also been shown. 6. The nature of this factor is at the present unknown; it is not a metal nor is it identifiable with many of the known coenzymes.
\end{abstract}

Methionine and its derivatives have been implicated as precursors of ethylene in plant tissues on the evidence (1) that model systems may be constructed containing $\mathrm{Cu}^{2+}$, ascorbate and/or hydrogen peroxide, which readily produce ethylene from the amino acid, in physiological concentrations and under physiological conditions of pH and temperature (Lieberman \& Mapson, 1964; Lieberman, Kunishi, Mapson \& Wardale, 1965), and (2) that the production of ethylene in apple slices is stimulated when methionine or its derivatives are infiltrated into the tissues (Lieberman, Kunishi, Mapson \& Wardale, 1966).

Most workers agree that the production of ethylene by fruits ceases when the cells are disintegrated. We, ourselves, have never been able to produce a cell-free extract from fruits that would continue to synthesize ethylene. We have thus tested other plant tissues and have found that extracts prepared from the florets of the cauliflowers may be induced to synthesize ethylene if methionine or its derivatives are added. The present paper deals mainly with the enzyme system involved in the synthesis of ethylene from methional, an intermediary in the synthesis of ethylene in the model systems described above.

\section{EXPERIMENTAL}

Cauliflowers. These were purchased from the local market, and normally used the same day. In some cases they were held for several days at $20^{\circ}$ to 'age'.

Methional. This compound was prepared from acrolein and methanethiol by the method described by Pierson, Giella \& Tishler (1948). It was identified by the melting point of its 2,4-dinitrophenylhydrazone, $117^{\circ}$.

Enzymes. Glucose oxidase (18-30 units/mg.) was purchased from Koch-Light Laboratories Ltd., Colnbrook, Bucks. Catalase and peroxidase from Sigma Chemical Co., St Louis, Mo., U.S.A., activity 2000-5000 Sigma units/mg. and 30 purpurogallin units/mg. respectively.

Preparation of enzyme extracts. The florets $(70 \mathrm{~g}$.$) of$ cauliflower, after separation from leaves and stalk, were ground in a mortar with $70 \mathrm{ml}$. of a chilled sucrose-phosphate solution (0.4 M-sucrose-0.1 M-sodium phosphate buffer, pH 7.4) and acid-washed sand. The mixture was pressed through muslin and centrifuged at $20000 \mathrm{~g}$ for $20 \mathrm{~min}$. to separate the particulate from non-particulate fractions: the final $\mathrm{pH}$ of the extracts was 7.2.

Fractionation with ammonium sulphate. The non-particulate fraction was brought to $30 \%$ saturation by the addition of $17.6 \mathrm{~g}$. of $\left(\mathrm{NH}_{4}\right)_{2} \mathrm{SO}_{4} / 100 \mathrm{ml}$. of solution. The precipitated protein was removed and the solution brought to $60 \%$ saturation by the further addition of $20 \mathrm{~g}$. of $\left(\mathrm{NH}_{4}\right)_{2} \mathrm{SO}_{4}$ / $100 \mathrm{ml}$. The precipitate was collected, dissolved in $5 \mathrm{ml}$. of 
0.1 M-sodium phosphate buffer, $\mathrm{pH} 7 \cdot 4$, and dialysed for $3 \mathrm{hr}$. or longer against the same buffer at $1^{\circ}$. Before use the solution was centrifuged. In later experiments the florets were extracted after maceration in a Waring Blendor.

Heated non-particulate fraction. The non-particulate fraction, isolated after removal of mitochondria and microsomes, was left to 'age' for 17-24 hr. at room temperature. It was heated at $100^{\circ}$ for $15 \mathrm{~min}$., cooled, filtered and concentrated in vacuo. In the separate experiments described in the text it was added to enzyme digests in amounts obtainable from $10-15 \mathrm{~g}$. of floret tissue.

Enzyme system for conversion of methional into ethylene. The enzyme system consisted of either the non-particulate fraction or the equivalent of the protein fraction precipitated by $30-60 \%$ saturation with $\left(\mathrm{NH}_{4}\right)_{2} \mathrm{SO}_{4}$, in $0.1 \mathrm{M}$-sodium phosphate buffer, pH7·0, containing EDTA (2mM) and methional (1 mM). These components were contained in a total volume of $10 \mathrm{ml}$., which also included glucose or glucose oxidase or both in amounts indicated in the separate experiments. The reaction mixtures were held in $50 \mathrm{ml}$. flasks sealed with rubber stoppers containing clamped capillary tubes. The flasks were incubated at $25^{\circ}$ and shaken. The internal atmospheres above the reaction mixtures were sampled periodically with a gas-tight syringe. Early experiments were carried out in atmospheres of $100 \%$ oxygen, but later only in air.

Estimation of ethylene. Gases produced in this reaction were determined by gas-liquid chromatography; a silicone

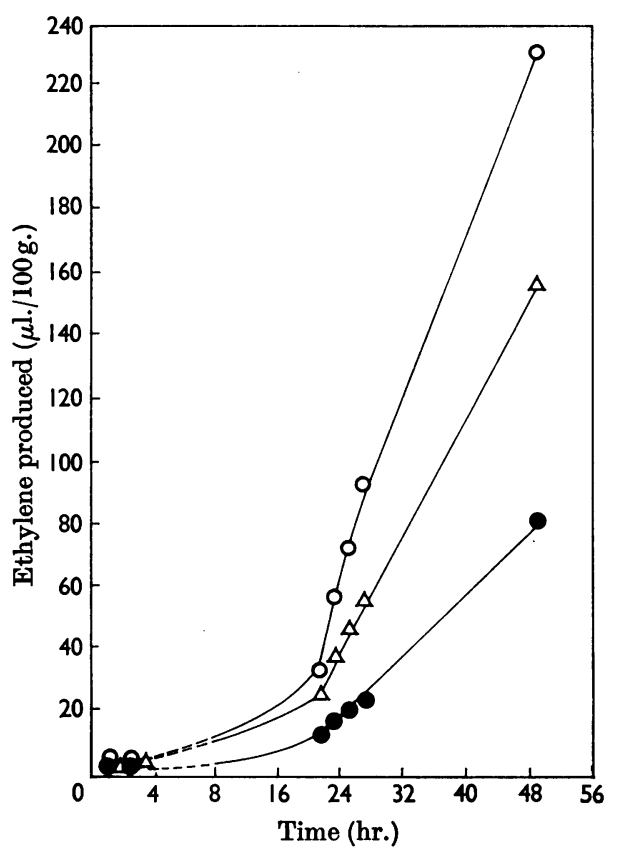

Fig. 1. Conversion of methionine or its hydroxy analogue into ethylene by florets. Cauliflower florets (15g.) were incubated in $20 \mathrm{ml}$. of $0.4 \mathrm{M}$-sucrose containing EDTA ( $1 \mathrm{mM}$ ); the atmosphere was $100 \% \mathrm{O}_{2}$. $\odot$, Control: O, methionine (5 $\mathrm{mM}) ; \Delta$, hydroxy analogue (5mM).
(30\% silicone oil on Celite) column and a flame ionization detector were used to determine ethylene (Meigh, Norris, Craft \& Lieberman, 1960).

\section{RESULTS}

Synthesis from intact florets. Synthesis of ethylene may be observed if the excised florets of the cauliflower are incubated in $0.4 \mathrm{M}$-sucrose at $25^{\circ}$ in oxygen. An atmosphere of oxygen rather than air was used in these initial experiments because we had found with apple slices (Lieberman et al. 1966) that the rate of synthesis was increased by raising the oxygen partial pressure. The rate of synthesis is very low during the first $15-20 \mathrm{hr}$. of incubation but then accelerates to give a steady rate of production (Fig. 1). As the results show the synthesis may be stimulated by the addition of methionine or its hydroxy analogue, but the addition of these compounds does not greatly alter the duration of the initial phase of inactivity. Once this has elapsed, however, the rate of synthesis is increased about threefold in the presence of methionine. These results agree with the results of comparable experiments carried out on apple slices.

In the model system that produces ethylene from methionine, or its derivatives, it was shown that a $\mathrm{Cu}^{2+} \mathrm{Cu}^{+}$system was operative, with the concentration of metal as low as $10-100 \mu \mathrm{M}$. The effect of EDTA (1 mM) on the reactions has been investigated, because this compound will largely eliminate catalysis due to $\mathrm{Cu}^{2+}$ or $\mathrm{Fe}^{3+}$ ions $(90 \%$ inhibition), the most active metal ions in the model system, but does not affect catalysis due to metalloprotein enzymes. A criterion of activity in the experiments reported in the present paper therefore was to determine if the reaction under investigation was diminished to any significant extent by the presence of EDTA at $1 \mathrm{~mm}$. All the reactions studied with extracts from cauliflower were unaffected by the presence of EDTA and lead us to conclude that they were not simply due to metal contamination in the extracts from the florets, or derived from external sources in the buffer salts. In general therefore to eliminate results due to simple metal catalysts we have employed EDTA (1-2mM) in all solutions used to prepare extracts and in all solutions used in the actual experiments.

Synthesis of ethylene in extracts. The demonstration that methionine stimulates the synthesis of ethylene in cauliflower florets prompted us to examine whether these reactions could be demonstrated in extracts. For this purpose, florets were extracted with a solution of $0.4 \mathrm{M}$-sucrose-0.1 Mphosphate buffer, $\mathrm{pH} 7 \cdot 4$, by grinding the tissue in a mortar with the addition of acid-washed sand. The extract was squeezed through muslin and used 
direct. This extract is referred to below as the whole extract.

This extract was further fractionated into particulate and non-particulate fractions by centrifuging at $60000 \mathrm{~g}$ for $30 \mathrm{~min}$., the particulate fraction being washed and recentrifuged. To each of these three fractions (whole extract, particulate and non-particulate) methionine, the hydroxy analogue of methionine or methional was added and the production of ethylene was followed by estimating its concentration in the atmosphere above the digests. The initial experiments were carried out in atmospheres of $100 \%$ oxygen, since it was found that the production of ethylene was dependent on the oxygen partial pressure: thus no conversion of methionine or its derivatives occurred in nitrogen and the rates of the reactions were all increased when oxygen replaced air.

The production of ethylene as affected by the addition of either methionine or its hydroxy analogue at a concentration of $5 \mathrm{~mm}$ for the whole extract, particulate and non-particulate fractions is shown in Fig. 2. Stimulation of the synthesis of ethylene was observed when either of these compounds was added to both the whole extract or to the mitochondria-microsome fractions, but no stimulation was observed when they were added to the non-particulate fraction. With both the particulate fraction and the whole extract, a phase of little activity was observed for periods varying between 4 and $20 \mathrm{hr}$. incubation, before the maximum rate of production of ethylene was observed, This behaviour was therefore similar to that observed with the intact florets. It was further demonstrated that these reactions were catalysed by heat-labile catalysts, since little or no activity resulted after the extracts had been heated at $100^{\circ}$ for 5-10 min.

When methional was used as substrate all these fractions formed ethylene but the rate of conversion by the particulate fraction alone was less than one-tenth of that of the non-particulate fraction (Fig. 3). These results, together with those illustrated in Fig. 2, indicate the existence of two distinct catalytic systems, the first confined to the mitochondria-microsome fraction, presumably converting methionine or its hydroxy analogue into a substance identical with or similar to methional, and the second system, mainly concentrated in the soluble part of the cytoplasm, catalysing the

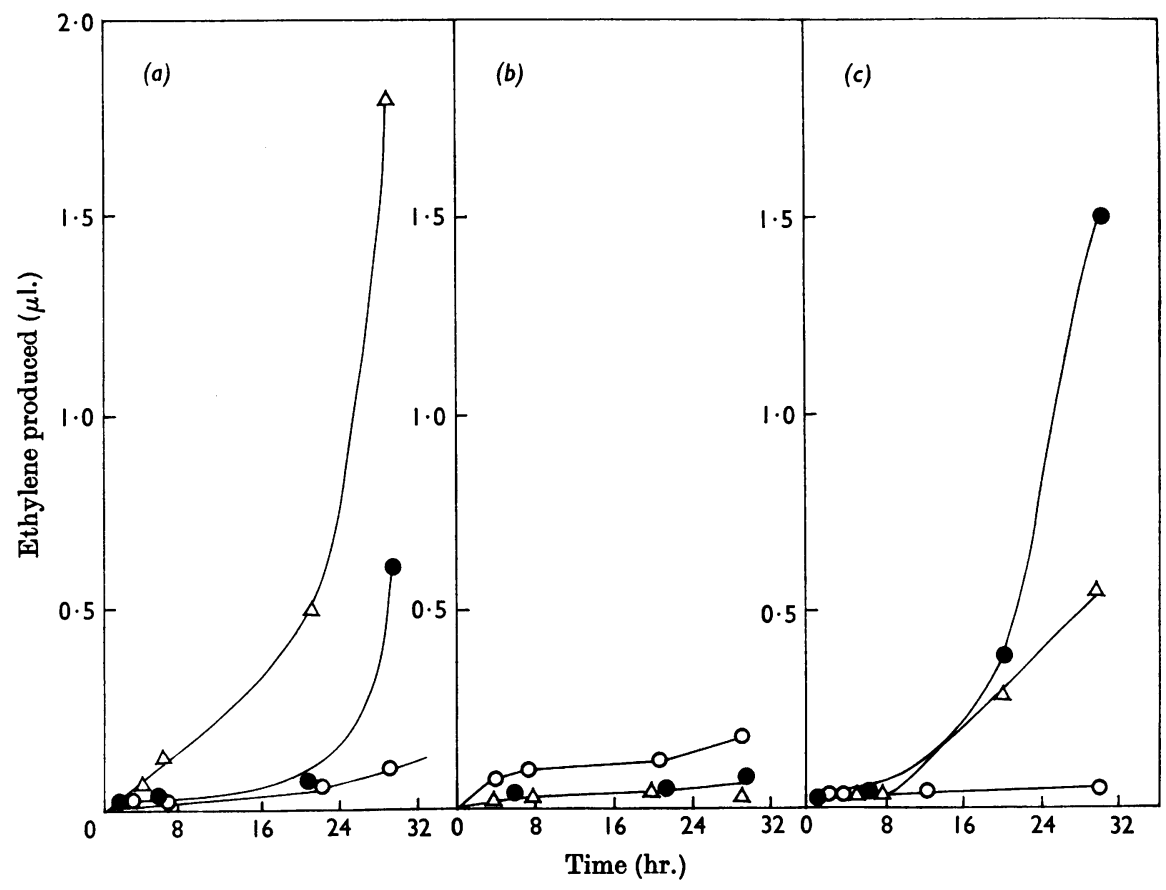

Fig. 2. Conversion of methionine or its hydroxy analogue into ethylene by cell-free fractions. (a) Whole extract (particulate and non-particulate), equivalent to $10 \mathrm{~g}$. of cauliflower; $(b)$ non-particulate extract; $(c)$ mitochondria and microsomes. All fractions were incubated in $0.4 \mathrm{M}$-sucrose-0.1 M-phosphate buffer, pH 7.4, containing EDTA (1 $\mathrm{mM})$; the atmosphere was $100 \% \mathrm{O}_{2}$. O, Control; $\bullet$, methionine (5mM); $\Delta$, hydroxy analogue (5 mM). 


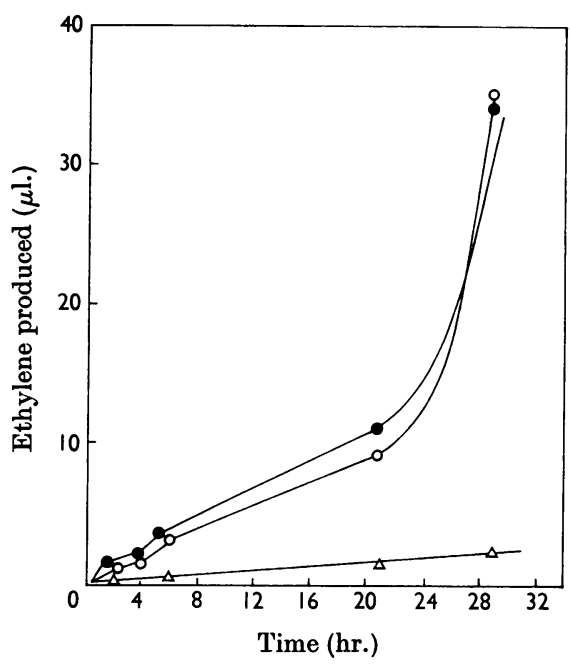

Fig. 3. Ethylene production from methional by cell-free fractions from florets. Conditions were as described in Fig. 2. $\bullet$, Whole extract (particulate and non-particulate), equivalent to $10 \mathrm{~g}$. of cauliflower; $O$, non-particulate extract; $\Delta$, mitochondria and microsomes.

breakdown of methional or a similar derivative to ethylene.

With both the whole extract and the nonparticulate fraction the production of ethylene from methional follows a progress curve similar to that observed with methionine, in that for the first $20 \mathrm{hr}$. there was a low and almost linear rate of production of ethylene, which increased rapidly after this period. In these experiments no other low-molecular-weight hydrocarbon other than ethylene has been detected, the other compound seen with certain extracts being acetaldehyde. The gas produced by these extracts in these experiments was shown to be ethylene by co-chromatography with a sample of pure ethylene.

Participation of hydrogen peroxide in the reaction. In work on the model systems it was established that a necessary participant in the reactions was hydrogen peroxide generated either in situ by the oxidation of $\mathrm{Cu}^{+}$ions or by the addition of hydrogen peroxide. In the conversion of methional into ethylene by non-particulate fractions from cauliflower florets, the participation of hydrogen peroxide is also required. Thus, as the results in Fig. 4(a) show, the addition of catalase severely inhibited the later phase of rapid production of ethylene, and conversely the generation of hydrogen peroxide in situ by the addition of glucose plus glucose oxidase (Fig. $4 b$ ) stimulated the reaction. The direct addition of hydrogen peroxide also stimulated but had generally less effect than if the hydrogen peroxide was generated in situ enzymically. The results in Fig. 4(b) show that, although the production of ethylene was stimulated initially by the addition of glucose and glucose oxidase, this acceleration in rate declined after a few hours. This may be due to the production of gluconic acid, which ultimately affects the $\mathrm{pH}$ of the solution; the reaction stops when the $\mathrm{pH}$ has fallen below $4 \cdot 5$.

The results illustrated in Fig. 4(a) show that the addition of catalase has no inhibitory effect on the low rate of ethylene formation in the earlier phase. This might indicate that this low rate of production is not dependent on the presence of hydrogen peroxide; however, the prompt response that occurred when this compound was generated in situ by the glucose-oxidase system suggests that its production was the limiting factor. The high reactivity of the ethylene-producing system with hydrogen peroxide may sustain a low rate of production even in the presence of catalase, the inhibitory effect of the latter only becoming apparent when hydrogen peroxide is being generated in greater amount. That the stimulative effect of the glucose-oxidase system was due to hydrogen peroxide seems to be indicated by the fact that the action of this enzyme may be neutralized by the simultaneous addition of catalase. In contrast with the effect of catalase, the addition of horseradish peroxidase to these extracts neither inhibited the formation of ethylene, nor stimulated it in the presence of added peroxide.

We have also demonstrated that the conversion of methionine or its hydroxy analogue into ethylene by the particulate and non-particulate fractions appear to be dependent on the generation of hydrogen peroxide. The inhibitory effect of catalase on the production of ethylene from the hydroxy analogue of methionine are shown in Fig. 4(c). The reaction follows a similar pattern to that observed with methional, but the rates of synthesis of ethylene are of a different order of magnitude.

'Aging' of florets. The failure of the extracts from fresh cauliflower florets to produce ethylene at any appreciable rate on the addition of methional thus appears to be due to the inability of the extract to generate hydrogen peroxide in any appreciable concentration. This situation could arise either from the lack of an active hydrogen peroxidegenerating system, or the presence of an active catalase enzyme. Conversely the phase of rapid activity that develops later may be due to development of a hydrogen peroxide-producing system or to the disappearance of an active catalase system.

The importance of 'aging' of the florets themselves is shown by the fact that non-particulate extracts from fresh as opposed to 'older' cauliflowers show a different behaviour on addition of methional. In the first case there was a period of 


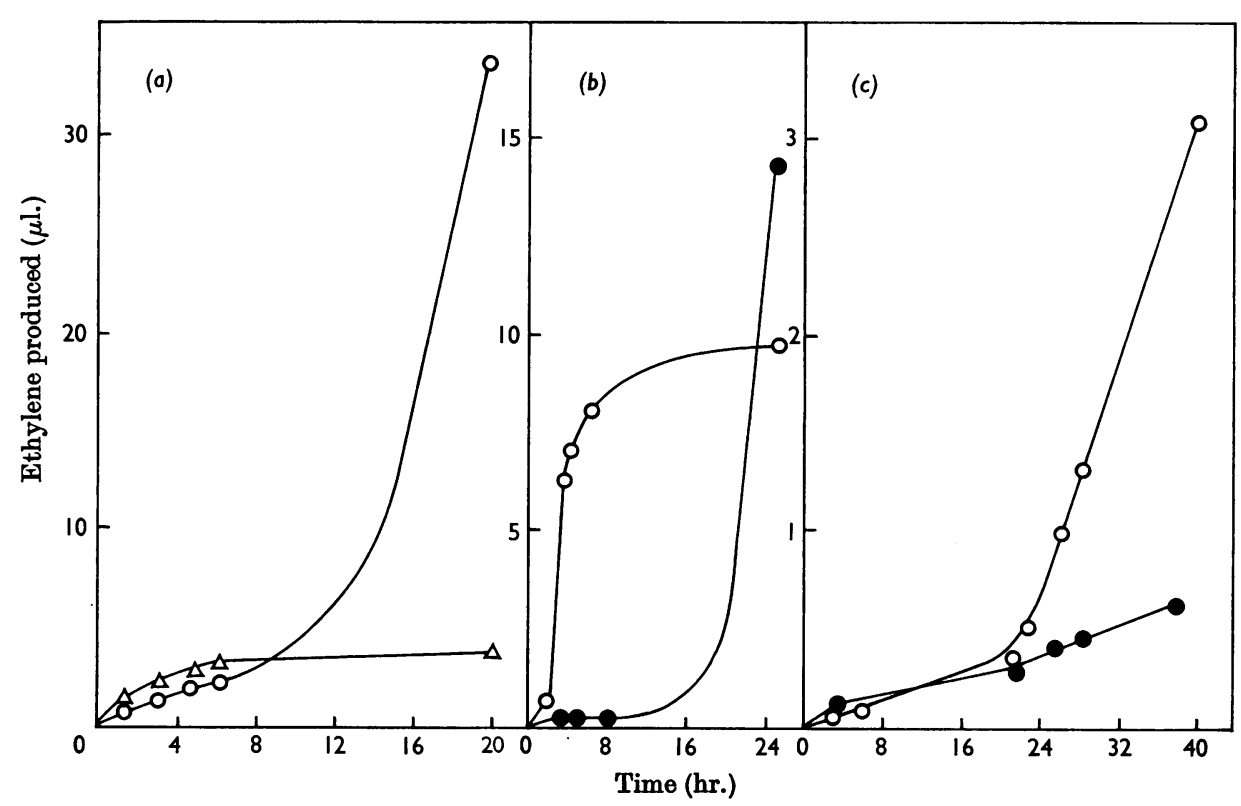

Fig. 4. Participation of hydrogen peroxide. Each flask contained $10 \mathrm{ml}$. of non-particulate or whole extract fraction in 0.4 M-sucrose-0.1 M-phosphate buffer, pH 7.4, containing EDTA (1 mM) and methional (1 mM) or the hydroxy analogue of methionine (5mM). (a) 0 , Non-particulate fraction + methional; $\Delta$, catalase (10 mg.) in addition. (b) Non-particulate fraction + methional; $O$, glucose $(1 \%, w / v)+$ glucose oxidase (1 mg.) in addition. (c) $O$, Whole extract (non-particulate + particulate) + hydroxy analogue; $\bullet$, catalase (10 mg.) in addition.



Fig. 5. Activity of non-particulate fractions prepared from 'young' and 'old' florets. Extracts from florets were incubated in 0.4 M-sucrose-0.1 $\mathrm{m}$-phosphate buffer, $\mathrm{pH} 7.4$, containing EDTA (1 mm). O, Extract from 'young' cauliflower + methional (1 mM); $\bullet$, glucose oxidase (1 mg.) in addition; $\Delta$, extract from 'old' cauliflower ('aged' by leaving at room temperature for 3 days)+methional (1 mM); $\square$, glucose oxidase (1 mg.) in addition. low activity that lasted for many hours before the rapid phase of activity supervened. With extracts from the more 'aged' florets this lag phase was greatly diminished and in some cases almost eliminated (Fig. 5). The maximum rate of ethylene production in the active phase is not, however, dissimilar in the two cases. In both cases the lag phase may be abolished by the addition of the glucose-oxidase system, but under such conditions the maximum rate of production of ethylene resulting therefrom was greater in the extract prepared from the 'aged' cauliflower as compared with that from the 'younger' vegetable.

'Aging' of extract. If the non-particulate fraction prepared from fresh florets is allowed access to oxygen at $15^{\circ}$ for $20 \mathrm{hr}$., the addition of methional to the solution at $25^{\circ}$ leads to a prompt production of ethylene; there is no preliminary phase of low activity as seen in the fresh extract (Fig. 6). The effect of temperature on this 'aging' process showed that the maximum response is obtained by holding the extract at $15^{\circ}$; at $1^{\circ}$ no activation occurs and the extract behaves like a freshly made extract; at $25^{\circ}$ activation is observed but the response to the addition of methional is less than at $15^{\circ}$. Also, the 'aging' process was prompted by an increase in the oxygen partial pressure in the atmosphere. Thus 


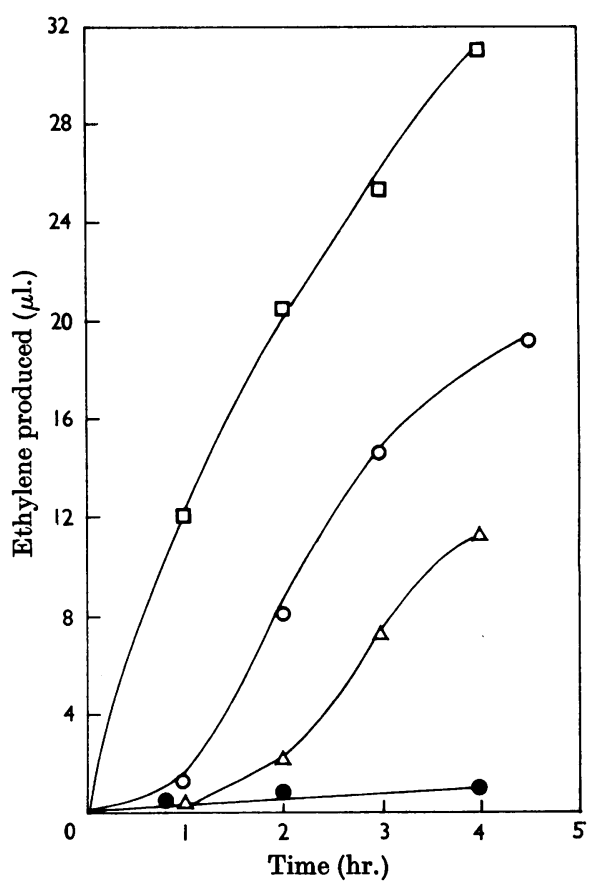

Fig. 6. 'Aging' of non-particulate fraction from fresh florets. Extracts from florets were incubated in $0.4 \mathrm{M}$ sucrose-0.1 M-phosphate buffer, pH 7.4, containing EDTA (1 $\mathrm{mM})$; methional (1 mM) was added at zero time. 9 , Fresh non-particulate fraction; $\Delta$, fraction held for $20 \mathrm{hr}$. at $15^{\circ}$ in $\mathrm{N}_{2}$; O, fraction held for $20 \mathrm{hr}$. at $15^{\circ}$ in air; $\square$, fraction held for $20 \mathrm{hr}$. at $15^{\circ}$ in $\mathrm{O}_{2}$.

the most rapid initial response occurred when methional was added to the non-particulate fraction that had been held in oxygen and the least with that held in nitrogen.

Since we have already established the need for hydrogen peroxide in these reactions, combined with the fact that the addition of a peroxidegenerating system eliminates the lag phase in the production of ethylene, the 'aging' of the nonparticulate extract would appear to promote, among other things, conditions for the endogenous production of peroxide.

These studies also revealed that, not only was the phase of low activity eliminated or decreased in extent on 'aging' the non-particulate extract, but that the maximum rate of ethylene production from methional on the addition of a peroxide-generating system was some four times as great with the 'aged' extract as with the 'fresh' extract, a result similar to that obtained with extracts prepared from 'young' and 'aged' florets. Such results indicate that the maximum ethylene-producing potential in the presence of non-limiting amounts of hydrogen peroxide was dependent on at least one factor other than the ability to form peroxide. To investigate this more closely attempts were made to fractionate the active components of the system.

Ammonium sulphate fractionation. Preliminary experiments showed that the enzyme or enzymes involved could be separated from the non-particulate fraction by precipitation with ammonium sulphate between the limits of $30-60 \%$ saturation, little if any activity being lost in the $0-30$ or 60 $100 \%$ saturation fractions. After a short (2hr.) dialysis against $0 \cdot 1 \mathrm{~m}$-phosphate buffer, $\mathrm{pH} 7 \cdot 0$, at $1^{\circ}$ the ability to convert methional into ethylene was greatly decreased and the response to the addition of glucose alone or glucose plus glucose oxidase was slight. Even if the ammonium sulphate fraction was prepared from either old cauliflowers or from an 'aged' non-particulate fraction the rate of formation of ethylene from methional was much lower than that observed with the untreated nonparticulate fractions. It seemed unlikely that simple fractionation with ammonium sulphate would have caused such a marked loss of enzymic activity. Accordingly fresh experiments were devised to find the reason for these differences.

A 30-60\%-saturated ammonium sulphate fraction was prepared from fresh cauliflower florets and dialysed for $16 \mathrm{hr}$. against $0.1 \mathrm{M}$-phosphate buffer, $\mathrm{pH} 7 \cdot 0$, at $1^{\circ}$. The addition of methional to this extract with or without the glucose-glucoseoxidase system gave a low but linear rate of formation of ethylene. If, however, to this extract was added an 'aged' non-particulate extract boiled to inactivate enzymes, the synthesis of ethylene from methional was stimulated tenfold (Fig. 7a); in the absence of methional no synthesis occurred. The inclusion of catalase decreased this rate of synthesis to a low value, indicating again the participation of peroxide (Fig. 7a). Moreover, the existence of an enzyme in the 30-60\%-saturated ammonium sulphate fraction able to produce peroxide, in the presence of added glucose, appeared likely, for this mixture supplemented with the heated nonparticulate fraction was capable, after a short delay, of sustaining a rapid production of ethylene from methional (Table 1). The enzyme may indeed be a glucose oxidase, for the only substance so far found capable of acting as substrate was D-glucose. One difference as noted earlier between this system and that of glucose-glucose oxidase was that whereas the activity of the latter led to a marked fall in $\mathrm{pH}$ no such fall occurred with the endogenous peroxide-producing system. These results have since been found to be due to the high concentration of glucose oxidase used, for this may be decreased 100-fold, and still initiate a rapid synthesis without any appreciable fall off in rate. A similar stimulation of ethylene production could be 


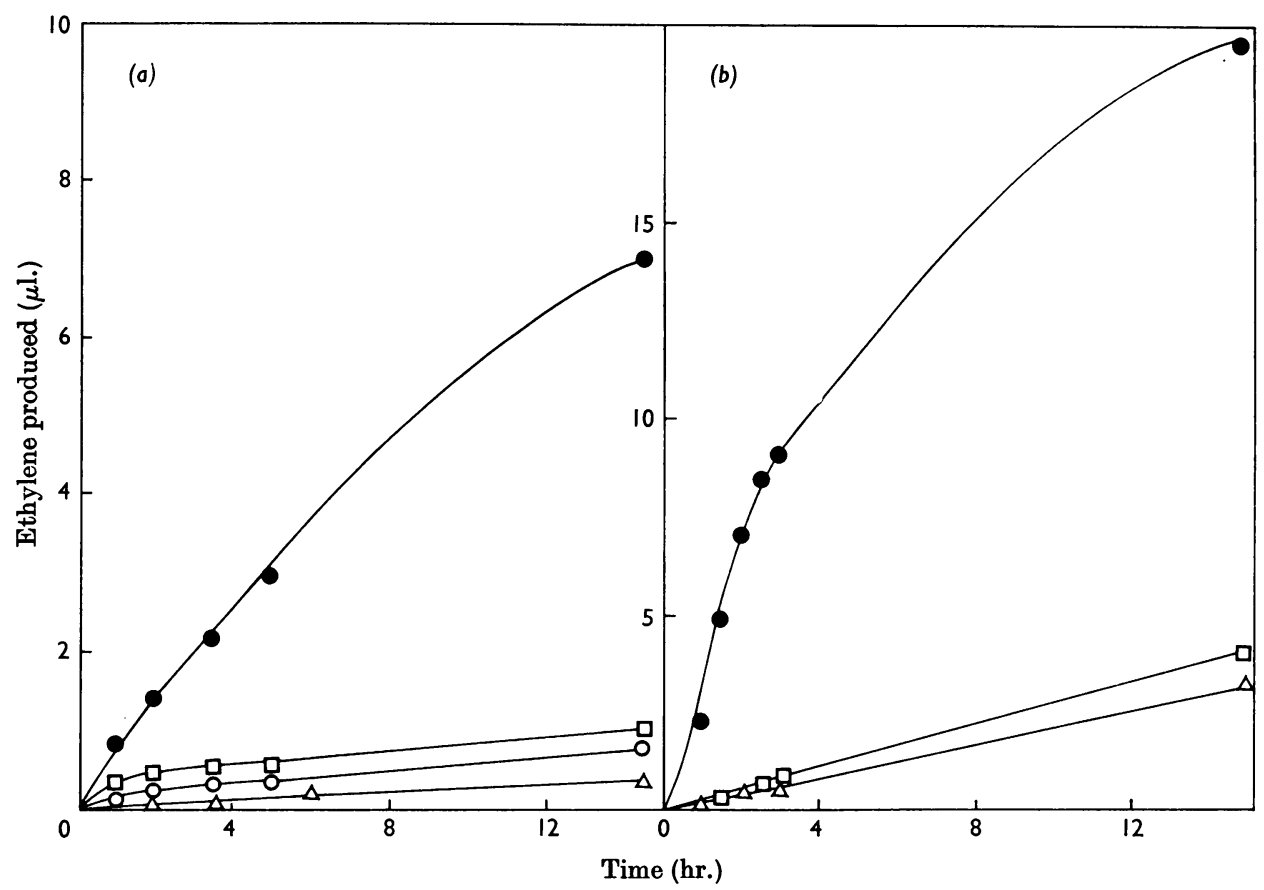

Fig. 7. Production of ethylene from methional by an enzyme fraction with and without supplementation by a heat-stable cofactor. The enzyme fraction was isolated from sucrose-phosphate extracts by precipitation with 30-60\%-saturated $\left(\mathrm{NH}_{4}\right)_{2} \mathrm{SO}_{4}$ and dialysed for $16 \mathrm{hr}$. against 0.1 M-phosphate buffer, pH 7.0. (a) $\Delta, 30-60 \%$ saturated $\left(\mathrm{NH}_{4}\right)_{2} \mathrm{SO}_{4}$ fraction + EDTA $(1 \mathrm{mM})+$ glucose $(1 \%, \mathrm{w} / \mathrm{v})+$ methional $(1 \mathrm{mM}) ; \mathrm{O}$, as $\Delta+$ glucose oxidase (1 mg.); $\bullet$, as $\Delta+$ heated non-particulate fraction previously held for $17 \mathrm{hr}$. at room temperature before heating; $\square$, as - catalase (10 mg.). (b) $\Delta, 30-60 \%$-saturated $\left(\mathrm{NH}_{4}\right)_{2} \mathrm{SO}_{4}$ fraction + EDTA (1 mM) + glucose (1\%, w/v) + methional (l $\mathrm{mm})$; $\bullet$, as $\Delta$ +heated non-particulate fraction; $\square$, as $\Delta+$ heated non-particulate fraction dialysed $24 \mathrm{hr}$. against three changes of sucrose-phosphate at $1^{\circ}$.

achieved by the addition of DL-alanine and $\mathrm{D}$-amino acid oxidase, although this was less efficient than the corresponding glucose-oxidase system.

The question remains as to whether the enzymic activity of the 30-60\%-saturated ammonium sulphate fraction could be related solely to its ability to catalyse the formation of peroxide from glucose or other substrates. This, however, was not the case, for, when the 30-60\%-saturated ammonium sulphate fraction was heated at $100^{\circ}$ to inactivate enzymes, this could not, even when supplemented with the peroxide-generating glucoseoxidase enzyme plus the heated non-particulate fraction, produce any significant amount of methional (Table 1). Also, when the 30-60\%saturated ammonium sulphate fraction was supplemented with the heated non-particulate fraction it readily produced ethylene from methional on the addition of hydrogen peroxide (Table 1), showing that the presence of glucose or glucose oxidase or both was necessary simply to produce peroxide.

The operation of these various factors are sum- marized in the results in Table 1 and point to the conclusion that the formation of ethylene from methional in this tissue is dependent on: (1) a peroxide-generating system; (2) the presence of an unknown heat-stable component; (3) an enzyme or enzymes reacting with methional in their presence.

Catalytic action of flavines. Abeles \& Rubinstein (1964) reported that ethylene was produced from an unknown substrate present in extracts from etiolated pea hypocotyls on the addition of FMN. In fact the rate of production of ethylene in this non-enzymic system was seven times as great as that produced in their enzyme reaction. We have found that all three flavines, riboflavine, FMN and FAD, are capable of catalysing the formation of ethylene from methional. These flavines act in this manner only when a peroxide-generating system is also present, as shown in the results in Fig. 8(a), in which only when the complete glucose-glucoseoxidase system was present was ethylene formed. The participation of a metal catalyst in these reactions is indicated by the marked inhibi- 
Table 1. Components involved in the enzymic formation of ethylene from methional

Flasks contained phosphate buffer, $\mathrm{pH} 7 \cdot 0(0 \cdot 1 \mathrm{M})$, methional $(1.0 \mathrm{~mm})$ and EDTA $(2 \mathrm{~mm})$ in a total volume of $10 \mathrm{ml}$. Flasks were incubated at $25^{\circ}$ for various times with shaking. The fraction precipitated by $30-60 \%$ saturated $\left(\mathrm{NH}_{4}\right)_{2} \mathrm{SO}_{4}$ was dialysed for $24 \mathrm{hr}$. against three changes of phosphate buffer, pH 7.0 $(0 \cdot 1 \mathrm{M})$, at $1^{\circ}$. Heated fractions were left for $10 \mathrm{~min}$. in boiling water and clarified. HNP, Heated non-particulate fraction.

Expt.

no. System

Ethylene formed ( $\mu \mathrm{l}$.

\begin{tabular}{|c|c|c|c|c|c|c|}
\hline & \multirow{2}{*}{\multicolumn{2}{|c|}{ Time (hr.).. }} & \multirow[b]{2}{*}{0.5} & & \multirow{2}{*}{5} \\
\hline & & & & 1 & 3 & \\
\hline 1 & $30-60 \%$-satd. $\left(\mathrm{NH}_{4}\right)_{2} \mathrm{SO}_{4}$ fraction & - & 0.01 & 0.05 & $0 \cdot 14$ & $0 \cdot 18$ \\
\hline 2 & $\begin{array}{l}30-60 \% \text {-satd. }\left(\mathrm{NH}_{4}\right)_{2} \mathrm{SO}_{4} \text { fraction }+ \\
\text { glucose }(1 \%, \mathrm{w} / \mathrm{v})+\text { glucose oxidase } \\
(1 \mathrm{mg} .)\end{array}$ & - & $0 \cdot 13$ & $0 \cdot 19$ & 0.5 & 0.72 \\
\hline 3 & $30-60 \%$-satd. $\left(\mathrm{NH}_{4}\right)_{2} \mathrm{SO}_{4}$ fraction $+\mathrm{HNP}$ & - & $0 \cdot 13$ & $0 \cdot 22$ & 0.77 & $2 \cdot 7$ \\
\hline 4 & $\begin{array}{l}30-60 \% \text {-satd. }\left(\mathrm{NH}_{4}\right)_{2} \mathrm{SO}_{4} \text { fraction }+\mathrm{HNP} \\
\quad+\text { glucose }(1 \%, \mathrm{w} / \mathrm{v})\end{array}$ & 一 & $0 \cdot 18$ & $0 \cdot 38$ & $3 \cdot 0$ & $8 \cdot 3$ \\
\hline 5 & $\begin{array}{l}30-60 \% \text {-satd. }\left(\mathrm{NH}_{4}\right)_{2} \mathrm{SO}_{4} \text { fraction }+\mathrm{HNP} \\
\text { + glucose + glucose oxidase }\end{array}$ & - & 11 & 13 & $16 \cdot 7$ & $17 \cdot 2$ \\
\hline 6 & As for 5 but no methional & - & - & 0.01 & 0.02 & 0.02 \\
\hline 7 & $\begin{array}{l}\text { As for } 5 \text { but } 30-60 \% \text {-satd. }\left(\mathrm{NH}_{4}\right)_{2} \mathrm{SO}_{4} \\
\text { fraction heated }\end{array}$ & - & $0 \cdot 29$ & 0.43 & $1 \cdot 0$ & $1 \cdot 2$ \\
\hline 8 & $\begin{array}{l}30-60 \% \text {-satd. }\left(\mathrm{NH}_{4}\right)_{2} \mathrm{SO}_{4} \text { fraction }+\mathrm{HNP} \\
+\mathrm{H}_{2} \mathrm{O}_{2}(1 \mathrm{mM})\end{array}$ & $2 \cdot 4$ & 4.9 & 4.9 & - & - \\
\hline
\end{tabular}

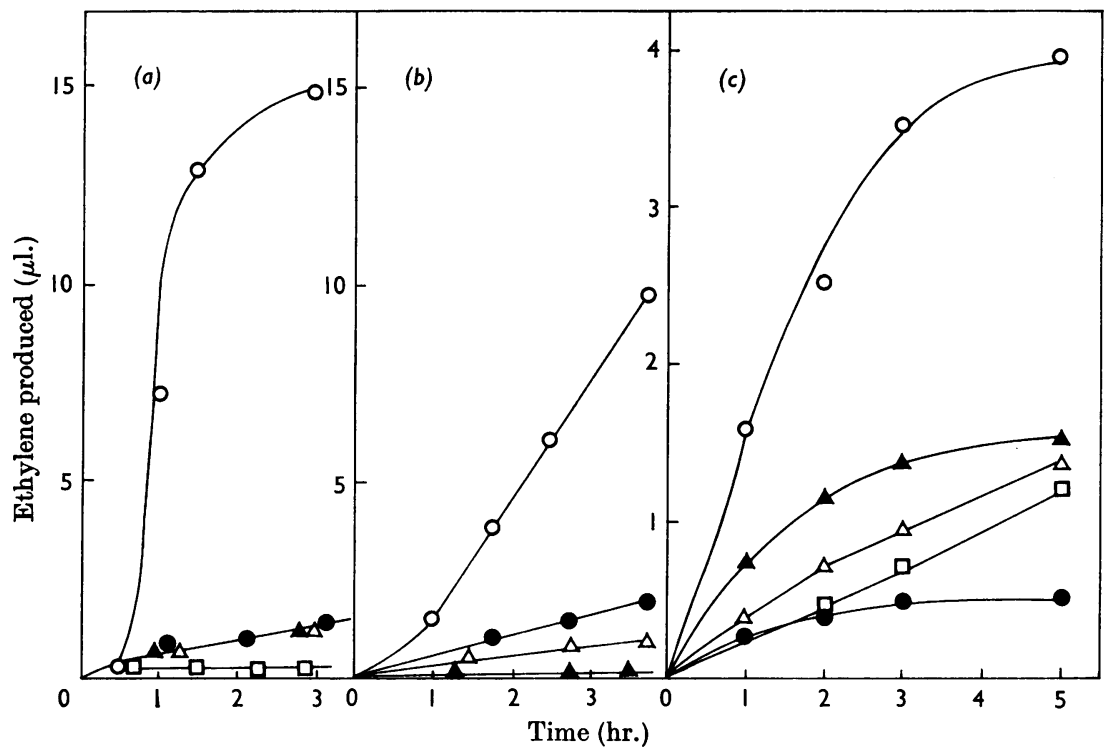

Fig. 8. Catalytic effect of flavines. (a) O, Phosphate buffer, pH $7 \cdot 4(0 \cdot 1 \mathrm{~m})+\mathrm{FAD}(70 \mu \mathrm{M})+$ glucose $(1 \%$, w/v) + glucose oxidase (1 mg.) + methional (1 mM); $\square$, as O, but no methional; $\triangle$, as O + EDTA (2 mM); $\bullet$, as $O$, but no glucose oxidase; $\Delta$, as $\mathrm{O}$, but no glucose. (b) O, Phosphate buffer, pH 7.4 (0.1 м) + FAD $(10 \mu \mathrm{M})+$ glucose $(1 \%$, $\mathrm{w} / \mathrm{v})+$ glucose oxidase (1 mg.) + methional (1 mM); $\bullet$, as $O+$ EDTA (5 mM); $\Delta$, as $O+$ sodium diethyldithiocarbamate (1 mM); $\triangle$, as O, but no FAD. (c) O, Phosphate buffer, pH 7.4 (0.1 M)+30-60\%-saturated $\left(\mathrm{NH}_{4}\right)_{2} \mathrm{SO}_{4}$ fraction +heated non-particulate fraction + glucose $(1 \%, \mathrm{w} / \mathrm{v})+$ glucose oxidase $(1 \mathrm{mg}$. $)+$ methional $(1 \mathrm{mM})+$ EDTA (2mM); e, as $O$, but no 30-60\%-saturated $\left(\mathrm{NH}_{4}\right)_{2} \mathrm{SO}_{4}$ fraction; $\square$, as $\bigcirc$, but no heated non-particulate fraction; $\Delta$, as $O$, but with heated non-particulate fraction replaced by FMN $(10 \mu \mathrm{M})$; $\Delta$, as $O$, but with heated non-particulate fraction replaced by FMN $(10 \mu \mathrm{M})$ and no $30-60 \%$-saturated $\left(\mathrm{NH}_{4}\right)_{2} \mathrm{SO}_{4}$ fraction.

tion observed when the chelating agents EDTA or sodium diethyldithiocarbamate were present (Fig. 8b).
In view of these results it was pertinent to inquire whether, in the enzymic reactions described above, the stimulative effect of the heated extract was 
due simply to the presence of free flavine. This was shown to be unlikely because in the first place the effect of the natural extract was not diminished in the presence of EDTA as was the case with flavines, and secondly no detectable amount of flavine (riboflavine, FMN or FAD) could be found after chromatographic analysis of the extract (Carter, 1950). If flavine was present it was certainly less than the amount necessary to account for the stimulating effect of the heated extract (Fig. 8c), a conclusion supported by the fact that the addition of the heated extract to a glucose-glucose-oxidase system did not catalyse the conversion of methional into ethylene above the low rate normally observed with the glucose-glucose-oxidase system in buffer alone.

Nature of cofactor. Only preliminary investigations have so far been carried out on the nature of the component responsible for the action of the heated extract. It is not identifiable with a number of the better known coenzymes. Thus the following substances when added to a 30-60\%-saturated ammonium sulphate fraction with the oxidase system and methional all failed to increase the rate of synthesis of ethylene: NAD, NADP, CoA, ADP, ATP, GSH, lipoate, dehydroascorbate, biotin, thiamine pyrophosphate, pyridoxal phosphate, indol-3-ylacetic acid and naphth-1-ylacetic acid.

The effectiveness of the heated non-particulate fraction was lost progressively on dialysis; after $5 \mathrm{hr}$. at $1^{\circ}$ its activity was decreased by half and after $24 \mathrm{hr}$. it was almost completely eliminated (Fig. 7b).

The effective agent does not appear to be a metal or to ionize as a base for it passed through a cationexchanger (Zeo-Karb 225, $\mathrm{H}^{+}$form) without loss. It does, however, appear to be acidic in character, for it was removed by passage through anion-



Fig. 9. Influence of $\mathrm{pH}$ on $(a)$ progress of the reaction and $(b)$ the system when peroxide is generated either endogenously by the addition of glucose or exogenously by the addition of $\mathrm{H}_{2} \mathrm{O}_{2}$ or glucose-glucose oxidase. (a) System: 30-60\%-saturated $\left(\mathrm{NH}_{4}\right)_{2} \mathrm{SO}_{4}$ fraction+EDTA (2 mM)+heated non-particulate fraction+ methional (1 mM) in 0.2 M-sodium phosphato-0.1 M-citric acid buffer at the appropriate $\mathrm{pH}: \square, \mathrm{pH} 4 \cdot 6 ; \Delta, \mathrm{pH} 5 \cdot 8$; O, pH 6.6; $\mathrm{q}, \mathrm{pH} 7 \cdot 2 ; \bullet, \mathrm{pH} 7 \cdot 6 ; \Delta, \mathrm{pH} 8 \cdot 2 ; \times, \mathrm{pH} 8 \cdot 9$. (b) System : $O$, as above;, with $\mathrm{H}_{2} \mathrm{O}_{2}(1 \mathrm{mM}) ; \Delta$, with glucose $(1 \%, \mathrm{w} / \mathrm{v})$ and glucose oxidase $(1 \mathrm{mg} . / 10 \mathrm{ml}$.$) .$ 
exchange resins [Dowex 2 (X8) and De-Acidite $\mathrm{H}$ ] and was eluted from silica gel with chloroform$n$-butanol under the conditions described by Wager \& Isherwood (1961).

Influence of $\mathrm{pH}$. The effect of $\mathrm{pH}$ on the activity of the system constituted by the 30-60\%-saturated ammonium sulphate enzyme fraction supplemented with the heat-stable cofactor and with glucose to promote the activity of the endogenous peroxideproducing enzyme has been determined. The duration of the initial phase of low activity was markedly prolonged at more alkaline pH (Fig. 9a). This effect of $\mathrm{pH}$ was almost certainly due to its influence on the peroxide-forming activity of the extract, for, if the above system was further supplemented with glucose oxidase, no lag phase was observed at any $\mathrm{pH}$. The maximum rate of production of ethylene after the lag phase in the system supplemented with glucose and cofactor alone occurred at about $\mathrm{pH} 6 \cdot 6$, falling fairly sharply at a more acid or alkaline pH (Fig. 9b). These observations represent the effect of $\mathrm{pH}$ on the whole system, and not necessarily the effect of $\mathrm{pH}$ on the methional-cleaving enzyme itself. Indeed, when this system was supplemented with glucose oxidase, the optimum $\mathrm{pH}$ was shifted to about 4.6. A more accurate estimate of the activity of the methionalcleaving enzyme in relation to $\mathrm{pH}$ was obtained by supplying hydrogen peroxide direct. In these experiments the peroxide was added to a 30-60\%saturated ammonium sulphate enzyme fraction supplemented with the heat-stable cofactor. A
pH-activity relationship was obtained similar to that with the added glucose-oxidase system, in that the optimum $\mathrm{pH}$ was shifted to more acid values compared with that obtained with the natural system. These results suggest that the more alkaline optimum $\mathrm{pH}$ in the latter case results from the effect of $\mathrm{pH}$ on the activity of the endogenous peroxide-generating system rather than on that of the methional-cleaving enzyme. On the other hand, the fall in activity on the alkaline side, which is similar in all three cases, probably represents the effect of $\mathrm{pH}$ on the activity of the methionalcleaving enzyme.

Inhibition. Copper chelators such as sodium diethyldithiocarbamate and cuprizone (biscyclohexanoneoxalyl dihydrazone) markedly inhibited the ethylene production by apple tissue slices, whereas EDTA had much less if any inhibitory effect. On this basis Lieberman et al. (1966) suggested that a copper enzyme system might be involved. We have examined these and other known copper-chelating agents on the reactions described in the present paper. The experiments were designed to show (1) the effect of these chelating agents on the overall system, i.e. including the peroxide-generating and methional-cleaving enzyme, and (2) their effect on the latter enzyme by measuring rates of reaction in the presence of added hydrogen peroxide, or in the presence of the glucose-glucose-oxidase system. The results (Table 2 ) indicate that the methional-cleaving enzyme is inhibited by these reagents, and there is also some

\section{Table 2. Effect of chelating agents}

All flasks contained phosphate buffer, pH7.0 (0.1 M), methional (1.0mM) and EDTA (2mM) in a total volume of $10 \mathrm{ml}$. In Expts. 1, 2 and 3 flasks were incubated at $25^{\circ}$ for $3 \mathrm{hr}$. with shaking and for $30 \mathrm{~min}$. in Expt. 4 . Chelating agents: dieca (sodium diethyldithiocarbamate); cuprizone (biscyclohexanoneoxalyl dihydrazone); cuproine (2,2'-biquinoline); neocuproine (2,9-dimethyl-1,10-phenanthroline).

Expt.

no.

System

Chelating agent...... Dieca

(1 mM)

1

'Aged' non-particulate fraction

2 Non-particulate fraction+ glucose $(1 \%, w / v)+$ glucose oxidase (l mg.)

3 'Aged' non-particulate fraction + glucose $(1 \%, \mathrm{w} / \mathrm{v})+$ glucose oxidase (1 mg.)

$4 \quad 30-60 \%$-satd. $\left(\mathrm{NH}_{4}\right)_{2} \mathrm{SO}_{4}$ fraction + heated 'aged' non-particulate fraction + $\mathrm{H}_{2} \mathrm{O}_{2}$ (mM)

Inhibition (\%)

$\begin{array}{ccccccc} & & & & 1,10- & & \\ \begin{array}{c}\text { Dieca } \\ (1 \mathrm{mM})\end{array} & \begin{array}{c}\text { Cuprizone } \\ (0 \cdot 1 \mathrm{mM})\end{array} & \begin{array}{c}\text { Cuproine } \\ (0 \cdot 1 \mathrm{mM})\end{array} & \begin{array}{c}\text { cuproine } \\ (0 \cdot 1 \mathrm{mM})\end{array} & \begin{array}{c}\text { anthroline } \\ (1 \mathrm{mM})\end{array} & \begin{array}{c}\text { Azide } \\ (1 \mathrm{mM})\end{array} & \begin{array}{c}\text { KCN } \\ (1 \mathrm{mM})\end{array} \\ 25 & 39 & 14 & 20 & 5 & 83 & 55 \\ 40 & 45 & 0 & - & 0 & - & - \\ 64 & 46 & - & - & - & - & -\end{array}$


suggestion that the activity of the endogenous peroxide-forming system may be adversely affected by diethyldithiocarbamate since the inhibition observed here was greater than that observed when peroxide was generated exogenously. In contrast with the effect of these chelators of $\mathrm{Cu}^{2+}$ ions, cuproine $\left(2,2^{\prime}\right.$-biquinoline) and neocuproine $(2,9$ dimethyl-1,10-phenanthroline), which chelate $\mathrm{Cu}^{+}$ ions, were ineffective, as was 1,10-phenanthroline, which readily chelates $\mathrm{Fe}^{3+}$ and $\mathrm{Fe}^{2+}$ ions. The compounds were also ineffective as inhibitors when infiltrated in apple tissue slices (L. W. Mapson, unpublished work). Both azide and cyanide were effective inhibitors even in the presence of added peroxide, which indicates a sensitivity of the methional-cleaving enzyme to these reagents.

In general the evidence supports our earlier contention that the ethylene-producing system in plant tissues is mediated by copper-containing enzymes, and suggests that only the metal in its cupric form is susceptible to chelation by reagents.

\section{DISCUSSION}

The results of the present experiments have shown (1) that the production of ethylene from intact cauliflower florets is stimulated in the presence of either methionine or its hydroxy analogue and (2) that the hydrocarbon is likewise formed from these compounds in the presence of an extract containing both the particulate and nonparticulate fractions, isolated from cell-free extracts. As with the model system previously described the most active precursor of ethylene so far found is methional. This compound may be converted into ethylene by an enzyme mainly concentrated in the non-particulate fraction of the cytoplasm. This enzyme acts in conjunction with peroxide and an unknown cofactor. There is as yet no substantial evidence that methional is the natural intermediate in the sequence of reactions leading to the formation of ethylene from methionine or its derivative. Indeed, as yet, in contrast with the results with cell-free extracts, we have been unable to demonstrate a marked stimulation of the synthesis of ethylene when methional is added or infiltrated into cauliflower florets.

From our results it would seem probable that the true intermediate, whether methional or an allied compound, is formed from methionine by an enzyme or enzymes located in the particulate fraction (mitochondria or microsome), this intermediate then being converted into ethylene by the enzyme system located in the non-particulate fraction of the cell.

There is a resemblance between the rate of production of ethylene from intact florets, incubated in a sucrose-phosphate solution, and the formation of ethylene from methionine, its hydroxy analogue or methional in extracts. In all cases the rate of formation of ethylene for the first few hours is very low, but accelerates rapidly after this phase of relative inactivity has elapsed. The present evidence suggests that the low rate of production in the initial phase is caused by the inability of the tissue or extract to produce peroxide in appreciable concentration. This concept is supported by the fact that the phase of rapid production of ethylene in sucrose-phosphate extracts from florets may be initiated by the addition of a peroxide-generating system or glucose-glucose oxidase, or delayed by the addition of catalase. We have further shown that the initial phase of low production is shortened or entirely eliminated if the non-particulate extract is 'aged', i.e. held at $15-25^{\circ}$ for about $24 \mathrm{hr}$. This 'aging' process may in fact result in an alteration in the balance of enzyme systems producing or destroying peroxide. Thus separation of these enzyme activities is partially achieved on fractionation of the extract. The fraction precipitated by $30-60 \%$-saturated ammonium sulphate, in the presence of its cofactor, will produce ethylene from methional immediately hydrogen peroxide (1 mM) is added. With the unfractionated extract the addition of similar amounts of peroxide in the phase of low activity has little or no effect, but on 'aging' of the extract ethylene production may likewise be stimulated by the addition of peroxide.

This concept suggests that the initiation of the synthesis of ethylene in this tissue is dependent, among other things, on the endogenous enzymic production of peroxide.

We have not attempted to determine (1) why the tissue or tissue extracts commence to generate peroxide in concentrations necessary for the reaction or (2) to identify the enzyme concerned. The onset of peroxide formation occurs, as several of our experiments indicate, quite abruptly. In many plant tissues also, e.g. banana fruit, the onset of the synthesis of ethylene occurs abruptly (Mapson \& Robinson, 1966), and, as in the experiments described above, is promoted by conditions (increase in oxygen partial pressure) that might be expected to favour the formation of peroxide. There are thus similarities between the results of our experiments with tissue extracts in vitro and the behaviour of many fruits in vivo.

There is evidence that the initiation of the rapid phase of synthesis of ethylene in either florets or extracts prepared from them may be delayed even longer than in the experiments described in the present paper. The present results were obtained from cauliflowers grown early in the season and imported into the U.K. By using cauliflowers obtained later in the season and grown locally, the rapid phase of synthesis of ethylene was not 
observed over a period of $48 \mathrm{hr}$. Whether the discrepancy was due to varietal differences or other factors is as yet uncertain. The ability of extracts from these cauliflowers to synthesize ethylene rapidly from methional could, however, as in the earlier experiments, be achieved by the addition of hydrogen peroxide, a fact that again indicates that the generation of a sufficient concentration of this substance may be essential.

The nature of the cofactor required for the operation of the methional-cleaving enzyme is at present unknown, save that it has acidic characteristics. Until this compound is identified it is useless to speculate as to its mode of action, though two possibilities appear to exist: it may act as a coenzyme for the enzyme or it may combine with methional to produce the true intermediate.

The nature of the methional-cleaving enzyme also requires further investigation, but from the present evidence it may well contain copper as an essential component of its prosthetic group.

\section{REFERENCES}

Abeles, F. B. \& Rubinstein, B. (1964). Biochim. biophys. Acta, 93, 675.

Carter, C. E. (1950). J. Amer. chem. Soc. 72, 1466.

Lieberman, M., Kunishi, A. T., Mapson, L. W. \& Wardale, D. A. (1965). Biochem. J. 97, 449.

Lieberman, M., Kunishi, A. T., Mapson, L. W. \& Wardale, D. A. (1966). Plant Physiol. 41, 376.

Lieberman, M. \& Mapson, L. W. (1964). Nature, Lond., 204, 345.

Mapson, L. W. \& Robinson, J. E. (1966). J. Fd Technol. $1,215$.

Meigh, D. F., Norris, K. H., Craft, C. C. \& Lieberman, M. (1960). Nature, Lond., 186, 902.

Pierson, E., Giella, M. \& Tishler, M. (1948). J. Amer. chem. Soc. 70, 1450.

Wager, H. G. \& Isherwood, F. A. (1961). Analyst, 86, 260. 